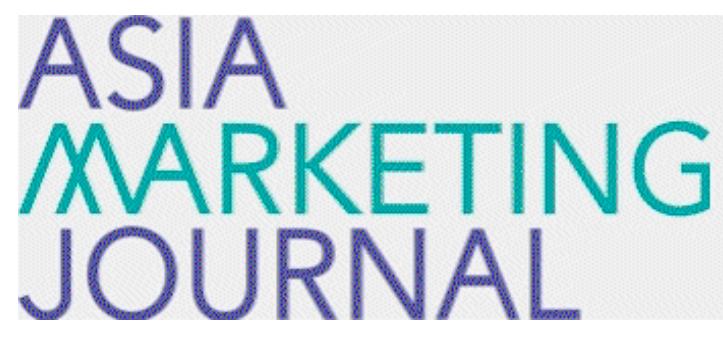

ASIA MARKETING JOURNAL

Volume 17 | Issue 2

Article 5

7-31-2015

\title{
The Impact of Servicescape on Customer Experience Quality through Employee-to-customer Interaction Quality and Peer-to- peer Interaction Quality in Hedonic Service Settings
}

Beomjoon Choi

Hyun Sik Kim

Follow this and additional works at: https://amj.kma.re.kr/journal

Part of the Marketing Commons

\section{Recommended Citation}

Choi, Beomjoon and Kim, Hyun Sik (2015) "The Impact of Servicescape on Customer Experience Quality through Employee-to-customer Interaction Quality and Peer-to-peer Interaction Quality in Hedonic Service Settings," Asia Marketing Journal: Vol. 17 : Iss. 2 , Article 5.

Available at: https://doi.org/10.15830/amj.2015.17.2.73

This Article is brought to you for free and open access by Asia Marketing Journal. It has been accepted for inclusion in Asia Marketing Journal by an authorized editor of Asia Marketing Journal. 


\section{The Impact of Servicescape on Customer Experience Quality through Employee-to-customer Interaction Quality and Peer-to-peer Interaction Quality in Hedonic Service Settings*}

Beomjoon Choi** Hyun Sik Kim***

This paper investigates how servicescape perception influences customer experience quality in hedonic service settings. In addition to the direct effect of servicescape quality on customer experience quality, the indirect effects of servicescape quality on customer experience quality via employee-to-customer interaction quality and peer-to-peer interaction quality are also investigated.

We collected data through a self-administered survey. The proposed relationships were tested using structural equation modeling.

The results show that servicescape quality influences customer experience quality both directly and indirectly through employee-to-customer interaction quality and peer-to-peer interaction quality, and customer experience quality influences customer loyalty. Additionally, we find that the indirect path via peer-to-peer interaction quality is significant only in a low-satisfaction customer group.

The indirect effect of servicescape quality perception through peer-to-peer interaction quality is significant only in low-satisfaction customer groups. Therefore, if evaluations for this indirect effect fall below an acceptable level, it should be addressed first before improving on other attributes. However, after this point, further improvements offer few if any gains; therefore, service firms should allocate their resources to quality improvements to other factors.

This study is the first to investigate the indirect effects of servicescape quality on customer experience quality via peer-to-peer interaction quality in hedonic service settings. Additionally, this study demonstrates that the significance of this indirect effect applies only to a low-satisfaction customer group.

Key words: servicescape, employee-to-customer interaction quality, peer-to-peer interaction quality, customer experience quality, customer loyalty, hedonic service settings

\footnotetext{
* This research was supported by Hallym University Research Fund (HRF-201406-002).

** Associate Professor, Department of Business Administration, California State University, Sacramento (bchoi@csus.edu)

*** Professor, School of Business, Hallym University (hshs@hallym.ac.kr), Corresponding Author
} 


\section{Introduction}

Creating superior customer experience is suggested as a way to achieve successful marketing outcomes (e.g., customer loyalty) and improve a firm's chances of success (Verhoef et al. 2009) in hedonic service settings. Nguyen et al. (2012) propose that, in hedonic services (e.g., going to a concert), the ultimate outcome of this consumption is the total experience of the performance (Ali et al. 2006; Berry et al. 2002; Hightower et al. 2002). Given its strategic importance, a few researchers (Lemke et al. 2011; Payne et al. 2008; Verhoef et al. 2009) have recently explored the relationship between customer experience quality and business success. Despite such efforts, customer experience quality and the antecedents and consequences of customer experience quality in hedonic service settings are not yet fully understood (Klaus and Maklan 2012).

To understand customer experience quality, it is imperative to distinguish customer experience quality from service quality. Service quality is a perceived judgment of the excellence of the service (Parasuraman et al. 1998; Zeithaml 1988), the focus of which lies in judgment about the firm's service process (Payne et al. 2008). On the other hand, customer experience is formed not only based on the communication encounter, the service encounter, and the consumption encounter, which are under control of the firm, but also numerous contextual factors, and hence, can be viewed as only partially influenced by the service firms (Lemke et al. 2011; Meyer and Schwager 2007; Pullman and Gross 2004; Schembri 2009). Hence, it may not be appropriate to assume that the antecedents of service quality apply to customer experience quality as well. In an attempt to research the antecedents and consequences of customer experience quality, we propose and test a theoretical model which includes antecedents such as servicescape, employee-tocustomer interaction quality, and peer-to-peer interaction quality as well as loyalty, the consequence of the customer experience quality.

The primary objectives of this study are fourfold. First, in order to examine the antecedents of customer experience quality, we examine the effect of servicescape quality, employeeto-customer interaction quality, and peer-topeer interaction (customer-to-customer interaction) on customer experience quality. Second, we examine the effects of customer experience quality on customer loyalty. Third, in addition to the direct effect of servicescape quality on customer experience quality, the indirect effects of servicescape quality on customer experience quality via employee-to-customer interaction quality and peer-to-peer interaction quality are also investigated. Fourth, the current study examines the moderating role of customer satisfaction level in the relationship between servicescape quality and peer-to-peer interaction 
quality and in the relationship between peerto-peer interaction quality and experience quality to check whether peer-to-peer interaction quality is a satisfier or a dissatisfier.

The current study offers two contributions. First, we propose and investigate the indirect effects of servicescape quality on customer experience quality via peer-to-peer interaction quality in hedonic service settings. To the best of our knowledge, this is the first study to address this indirect influential path. The current study firstly examines the influential path from servicescape to experience quality via peer-topeer quality, which is different from existing studies on peer-to-peer quality (e.g., Kim and Choi 2013) that only examine the impacts the construct. Second, the present study is the first to examine the moderating effect of the level of customer satisfaction on the relationship between servicescape quality and peer-to-peer interaction quality, and the relationship between peer-to-peer interaction quality and experience quality in hedonic service settings. These differences will give managers and academicians more plentiful implications.

To test the model, we conducted a survey and collected self-administered data for analysis. The proposed relationships were then tested using structural equation modeling. The rest of the study is organized as follows. The next section provides a theoretical model along with the proposed hypotheses. The methodology section describes the research methods, followed by the results section that discusses the findings. Finally, the paper concludes with a discussion of the implications, limitations, and opportunities for future research.

\section{Theoretical Model and Hypotheses Development}

\subsection{Servicescape and customer experience quality}

Service quality and customer satisfaction, which are considered key elements for business success, have been investigated by numerous researchers in marketing, retailing, and service management (e.g., Parasuraman et al. 1988; Verhoef et al. 2007). Customer experience quality, on the other hand, has only been studied recently by a few researchers, (e.g., Lemke et al. 2011; Verhoef et al. 2009) though it seems that practitioners had already considered customer experience a crucial factor for engendering loyalty (Badgett et al. 2007). Verhoef et al. (2009) proposed a conceptual model of customer experience and suggested several determinants of customer experience quality, which include the social environment, service interface, retail atmosphere, assortment, price, and promotions. In the present study, we suggest servicescape as one of the determinants of customer experience quality. 
Servicescape is a widely used term to describe the physical surroundings of any service firm (Reimer and Kuehn 2005). Servicescape (Bitner, 1992, p.58) refers to "the built environment that is the manmade physical surroundings as opposed to the natural or social environment." Servicescape includes the space factor such as layout, equipment, and ambient conditions such as temperature, music, noise, odor, as well as tangible parts of the service such as signage, brochures, and other communication material (Bitner 1992; Reimer and Kuehn 2005). Bitner (1992) argues that servicescape exerts influence on consumer experience. For example, a traveler may have a horrible experience at the airport because she or he has a hard time finding signage providing directions to the assigned gate, and feels stress due to crowds, high temperature, and a small number of restrooms. Brady and Cronin (2001) also posit that servicescape quality, in addition to social factors, are critical in assessing the quality of a service encounter. In addition, customer experience is understood as the customer's subjective response to the direct and indirect encounter with the firm (Lemke et al. 2011). Therefore, we suggest that servicescape quality is a critical determinant of customer experience quality and hypothesize:

H1: Servicescape quality will have a positive influence on customer experience quality.

\subsection{Servicescape, employee-to-customer interaction quality, and customer experience quality}

Employee-to-customer interaction quality refers to the customers' perceptions of the manner in which the service is delivered (Lemke et al. 2011) and the interactions between employees and customers during service delivery (Brady and Cronin 2001; Grönroos 1982, 1984). Physical surroundings are important in service settings because the nature and quality of customer and employee interaction are affected by the physical space in which it occurs. "In studies on servicescape, the focus has shifted towards social relationships between customers and between employees and customers" (Caru and Cova 2015). Caru and Cova (2015) posit that servicescape's design contributes to socialization between customers and staff. Forgas (1979) argues environmental elements such as seating arrangement, proximity, size, and flexibility define the possibilities for and limits of social interaction. For example, seating arraignments at restaurants may encourage interactions between customers and a chef who prepares meals in full view. As such, physical settings affect the nature and quality of social interactions by facilitating or hindering interactions between customers and employees (Bitner 1992). Reimer and Kuehn (2005) posit that a disorganized service provider's office may not only suggest poor service quality, but also unreli- 
ability on the part of the service provider herself. Therefore, we propose that servicescape quality is a critical determinant of employeeto-customer interaction quality, and therefore hypothesize:

H2.1: Servicescape quality will have a positive influence on employee-to-customer interaction quality.

From the initial contact with a service provider, customers interact with service providers across multiple touch points (e.g., making an appointment or reservation, contact from a receptionist for a reminder, receiving service from a service provider). The customer experience is likely to be determined based on a set of interactions between a customer and a product, company, or part of its organization (LaSalle and Britton 2003; Shaw and Ivens 2005). In particular, interactions with employees involved in the service experience are likely to enhance the customer experience quality. For example, if employees are polite, responsive, friendly, and helpful in dealing with customers during service encounters, customers are more likely to perceive a high level of experience quality. Therefore, we propose that customer experience quality is determined based on the perceived quality of interactions between customers and employees, and therefore, hypothesize:

H2.2: Employee-to-customer interaction qual- ity will have a positive influence on customer experience quality.

\subsection{Servicescape, peer-to-peer interaction quality, and customer experience quality}

Aubert-Gamet and Cova (1999) argue social interactions are affected by the physical setting in which they occur. Behaviors such as participation, assistance, small group interaction, aggression, group cohesion, and friendship formation are facilitated or inhibited by the physical settings (Bitner 1992; Harris and Baron 2004; Sundstrom and Sundstrom 1986). "Servicescape's design contributes not only to socialization between customers and staff, but also among customers" (Caru and Cova, 2015, p.278). Characteristics of the physical settings such as the facilities, layout, music, scents, and temperature (ambient cues) influence approach (e.g., engage in valuable and helpful behavior toward other customers, share experiences with others, etc.) and avoidance (e.g., limited interaction with other customers) behaviors (North 2003; Spangenberg 1996). For example, seating arrangements in airports discourages comfortable conversation among travelers (Sommer 1974). Similarly, disorganized seating arrangement in a concert hall may not only signal bad service experience quality, but also unreliability of the peer-to-peer interaction. Therefore, we propose that peer-to-peer interaction quality is determined 
based on the perceived quality of the servicescape, and therefore, hypothesize:

\section{H3.1: Servicescape quality will have a pos- itive influence on peer-to-peer inter- action quality.}

Lemke et al. (2011) state "one of the origins of customers experience is the contact with other customers in the consumption process...customers view the quality of the peerto-peer encounter as part of their overall experience assessment." McGroth and Otnes (1995) posit that a customer's helping behavior directly influences other customers' service experience. Wu (2007) also argues that knowledgeable customers influence other customers' experience by disseminating useful customer knowledge and tips. On the other hand, a customer's misbehavior affects other customers' service experience negatively: jay customer behaviors (Lovelock 1994), deviant customer behavior (Moschis and Cox 1989), and aberrant customer behavior (Fullerton and Punj 1993) ruin the experience for other customers (Verhoef et al. 2009). Customers can also influence one another indirectly (Tombs and McColl-Kennedy 2010). For example, crowding or standing too close to others may create anxiety, thereby influencing other customers' experiences (Bateson and Hui 1986; Fisher and Byrne 1975). “A sporting event would benefit from having a supportive crowd and a concert would benefit from fans that can play a part in the overall experience by singing along with the band" (Nguyen et al., 2012, p. 269). This leads us to suggest that there exists a positive relationship between peer-to-peer interaction quality and customer experience quality. Therefore, we hypothesize:

H3.2: Peer-to-peer interaction quality will have a positive influence on customer experience quality.

\subsection{Customer experience quality and customer loyalty}

Loyalty is defined as "an intention to perform a diverse set of behaviors that signal a motivation to maintain a relationship with the focal firm, including allocating a higher share of the category wallet to the specific service provider, engaging in positive word of mouth, and repeat purchasing" (Siredeshmukh et al., 2002, p. 20). Previous research suggests that service quality and customer satisfaction are two major antecedents of loyalty towards firms: Parasuraman et al. (1998) suggest a direct link between service quality and loyalty. We posit customer experience quality as one of the key antecedents of loyalty. Customer experience quality is conceptually distinct from service quality. Service quality is considered a perceived judgment of service excellence (Parasuraman et al. 1998; Zeithaml 1988), the focus of which lies in judgment about the firm's service proc- 
ess (Payne et al. 2008). On the other hand, customer experience is formed based on numerous contextual factors (e.g., contact with other customers, a level of participation in a service process), and hence, is only partially influenced by service firms (Pullman and Gross 2004; Schembri 2009).

Our conceptualization of "customer experience" deals with customers' perception of "total experience," which depends on not only the perceived quality of services provided but also other elements which influence customer experience. For example, our experience at Starbucks may not be based solely on the taste of freshly brewed café mocha and the employee service but also on presence of and interaction with other customers. Customers often $\mathrm{co}^{-}$create their unique experience with the company when companies provide the servicescape and contexts conducive to experiences (Prahalad and Ramaswamy 2004; Caru and Cova 2007). Positive customer experience is likely to create an emotional tie between the firm and customers and engender customer loyalty. Based on the arguments provided above, it is likely that satisfactory customer experiences lead to customer loyalty. Therefore, we hypothesize:

H4: Customer experience quality will have a positive influence on customer loyalty.

\subsection{Satisfier vs. dissatisfier in hedonic services}

Ng et al. (2007) suggests that hedonic services are personal and grounded in individual attitudes and motivations related to the consumption experience (Albers-Miller and Stafford 1999). Ng et al. (2007) posits that hedonism reflects characteristics such as pleasure, enjoyment, or delight (O’Shaughnessy and O'Shaughnessy 2002), and argue that hedonic services highlight the importance of experiencing personal pleasure and enjoyment during the service consumption episode (O'Shaughnessy and O'Shaughnessy 2002). Therefore, hedonic services are consumed to fulfill psychological needs and the service outcome is evaluated based on the customers' enjoyment of the experience (Cooper-Martin 1992; Ng et al. 2007). Nguyen et al. (2012) propose that, in hedonic services (e.g., going to a concert), the ultimate outcome of this consumption is the total experience of the performance (Ali et al. 2006; Berry et al. 2002; Hightower et al. 2002). Other customers (e.g., crowds, the social servicescape) have a significant impact on the total customer experience in hedonic service settings (Berry et al. 2002; Nguyen et al. 2012). Nguyen et al. (2012) suggest diverse examples such as "creating noise in a quiet environment such as talking, laughing loudly, expressing negative/positive emotion through talking or arguing with others, commenting about the service provider or us- 
ing inappropriate language, or children misbehaving in public" (Nguyen et al., 2012, p. 269). In hedonic service settings, "a supportive crowd in the proper environment would have a positive influence on the atmosphere of the event, and hence, positively affect the consumer's total experience" (Nguyen et al., 2012, p. 269). Extending this line of research, we suggest that, in hedonic service settings, peer-topeer interaction quality and its influential factors (e.g., servicescape quality) are all basic factors (dissatisfiers) rather than excitement factors (satisfiers) or performance factors, possibly indicating that these will affect customer experience quality differently depending on the level of satisfaction.

Matzler et al. (2004, p. 273) propose that "basic factors (dissatisfiers) are minimum requirements that cause dissatisfaction if not fulfilled but do not lead to customer satisfaction if fulfilled or exceeded; negative performance on these attributes has a greater impact on overall satisfaction than positive performance. The fulfillment of basic requirements is a necessary, but not sufficient condition for satisfaction. Basic factors are entirely expected. The customer regards them as prerequisites; they are taken for granted." On the contrary, "excitement factors (satisfiers) are the factors that increase customer satisfaction if delivered but do not cause dissatisfaction if they are not delivered; in other words, positive performance on these attributes has a greater impact on overall satisfaction than negative performance. Excitement factors surprise the customer and generate "delight"” (Matzler et al. 2004, p. 273). Additionally, Matzler et al. (2004, p. 273) suggest, "performance factors lead to satisfaction if performance is high and to dissatisfaction if performance is low. In this case, the relationship between service attribute performance and overall satisfaction is linear."

In sum, we posit that peer-to-peer interaction quality and the influential factors involved in it (e.g., servicescape quality) are critical in forming customer experience quality perceptions, particularly in a low satisfaction group but not in a high satisfaction group. In a highly satisfied customer group, there will be no noticeable significant link between servicescape quality and customer experience quality via peer-to-peer interaction quality. In contrast, in a dissatisfied customer group, there will be a noticeable significant link between servicescape quality and customer experience quality via peerto-peer interaction (e.g., the unpleasant feelings when they suffer from neighboring customers' misbehavior may be severe). Therefore, the level of customer satisfaction is expected to serve as a moderator between servicescape quality and peer-to-peer interaction quality, and peer-to-peer interaction quality and customer experience quality, and we state the following hypothesis.

H5: The impact of servicescape quality on peer-to-peer interaction and the impact 
of peer-to-peer interaction quality on customer experience quality will be significant in a low-satisfaction customer group, however, not in a high-satisfaction customer group.

In all, the servicescape quality influences customer experience quality directly and indirectly through employee-to-customer interaction quality and peer-to-peer interaction quality, which, in turn, affects customer loyalty. Figure 1 illustrates the research model for this study.

\section{Research Methodology}

\subsection{Sample}

Three hundred fifty four mid-sized college students in Korea participated in the survey for extra credit, conducted in a self-completed questionnaire format. Through the pilot study (sample size 30), movie theatres, museums, tours, and theme parks were selected as the most popular hedonic services. After being exposed to the definition and illustrative categories of hedonic services (Ng et al. 2007), subjects were asked to recall their most recent hedonic service experience among them. They were asked to write down the organization's name to enhance recall accuracy. The sample was $48.9 \%$ male. The various service types reported in the sample are expected to enhance the applicability of the current research findings to most hedonic service categories.

\subsection{Measures}

Based on the previous research on service

\section{〈Figure 1〉 Research model}

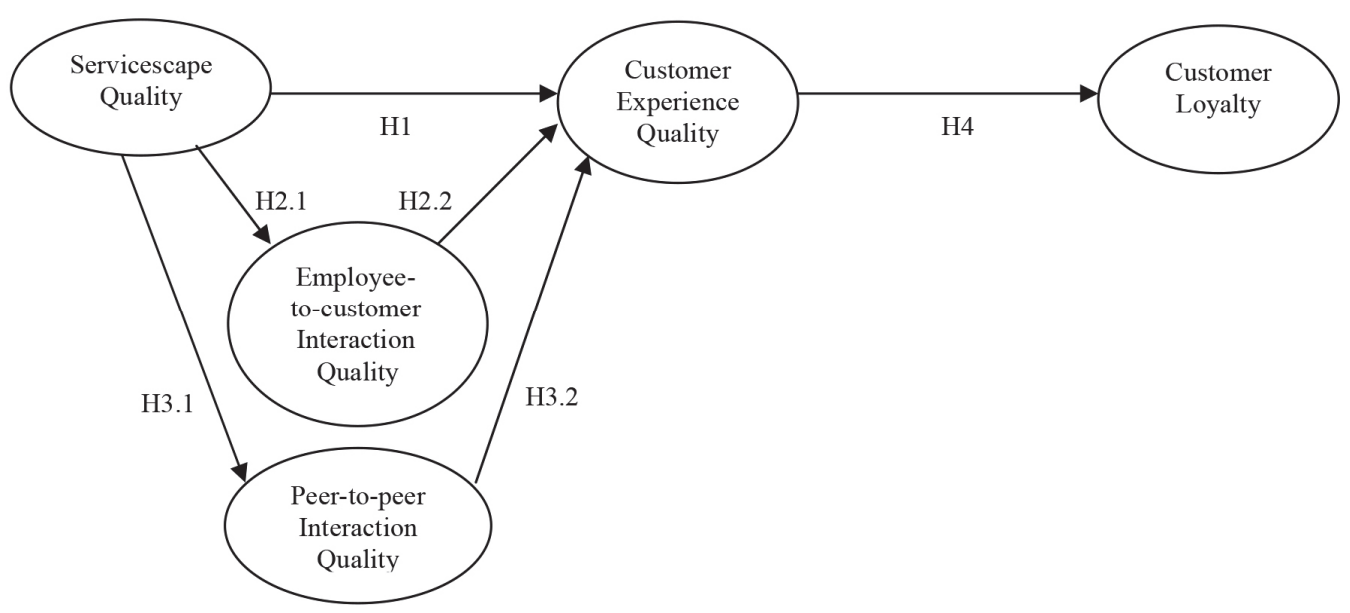

The Impact of Servicescape on Customer Experience Quality through Employee-to-customer Interaction Quality and Peer-to-peer Interaction Quality in Hedonic Service Settings 81 
marketing, we select measurement items deemed appropriate to the context of the current study. Adopting measurement items used in the existing literature provided a basis for the specification of each construct. Measurement items were either taken directly or modified to measure the latent constructs. All measures used for the current study are shown in Table 1. The subjects were asked to respond on a five-point
Likert scale, ranging from 1 (strongly disagree) to 5 (strongly agree). For cross-validation of survey questionaire, two bilingual experts fluent in both English and Korean translated the questionnaire into Korean. Following Douglas and Craig's (1983) recommendation, the verbal equivalence between the Korean and English versions was checked through back-translation by two other bilinguists.

〈Table 1〉 Measurement items.

\begin{tabular}{|c|c|c|}
\hline Construct & Measurement items & References \\
\hline $\begin{array}{c}\text { Servicescape } \\
\text { Quality }\end{array}$ & $\begin{array}{l}\text { The overall quality of XYZ's facility is great (V1). } \\
\text { The overall quality of XYZ's facility is much better } \\
\text { than I expected (V2). } \\
\text { The overall quality of XYZ's facility is just what it } \\
\text { should be (V3). }\end{array}$ & Wakefield and Blodgett (1996) \\
\hline $\begin{array}{l}\text { Employee-to- } \\
\text { customer } \\
\text { Interaction } \\
\text { Quality }\end{array}$ & $\begin{array}{l}\text { I think that the quality of my interaction with XYZ } \\
\text { and XYZ's employees is excellent (V4). } \\
\text { I would say that XYZ and XYZ's employees are } \\
\text { interested in customers (V5). } \\
\text { I believe that XYZ and XYZ's employees care about } \\
\text { customers (V6). }\end{array}$ & $\begin{array}{l}\text { Brady and Cronin (2001) } \\
\text { Choi and Kim (2013) }\end{array}$ \\
\hline $\begin{array}{l}\text { Peer-to-peer } \\
\text { Interaction } \\
\text { Quality }\end{array}$ & $\begin{array}{l}\text { I would say that the quality of my interaction with } \\
\text { other customers at XYZ is excellent (V7). } \\
\text { I believe that we have superior interactions with other } \\
\text { customers at XYZ (V8). } \\
\text { I think that the total contact with other customers at } \\
\text { XYZ is excellent (V9). }\end{array}$ & $\begin{array}{c}\text { Choi and Kim (2013) } \\
\text { Lemke, Clark, and Wilson (2010) }\end{array}$ \\
\hline $\begin{array}{l}\text { Customer } \\
\text { Experience } \\
\text { Quality }\end{array}$ & $\begin{array}{l}\text { I would say that the experience at/with } \mathrm{XYZ} \text { is } \\
\text { excellent (V10). } \\
\text { I believe that we have a superior experience at XYZ } \\
\text { (V11). } \\
\text { I think that the total experience procedure at XYZ is } \\
\text { excellent (V12). }\end{array}$ & $\begin{array}{c}\text { Kim and Choi (2013) } \\
\text { Lemke, Clark, and Wilson (2010) }\end{array}$ \\
\hline $\begin{array}{l}\text { Customer } \\
\text { Loyalty }\end{array}$ & $\begin{array}{l}\text { When choosing the same product category, I will } \\
\text { consider XYZ as my first choice (V13). } \\
\text { I will continue to visit XYZ in the future (V14). } \\
\text { I will continue to visit XYZ, even if other alternatives } \\
\text { are available (V15). }\end{array}$ & Yim, Tse, and Chan (2008) \\
\hline
\end{tabular}


According to Podsakoff et al.'s (2003) recommendation, we designed the survey to minimize common method variance. First, we collected only limited personal information (e.g., gender) so as to ensure anonymity. Second, we separated each section of the questionnaire from the other sections so as to ensure clarity. Third, we conducted the Harman's singlefactor test (e.g., Podsakoff et al. 2003) as a post hoc analysis to examine common method bias. The test shows that no single factor accounts for most of the variance in the variables. These results may alleviate concerns about common method variance in our model.

\section{Analysis and Results}

\subsection{Measurement model}

The adequacy of the measurement model was evaluated based on overall fit with the data, reliability, convergent validity, and discriminant validity. First, reliability and validity tests of the measurement model were conducted (Churchill, 1979). The properties of all items were located as reflective measures on their respective factors and evaluated through a comprehensive confirmatory factor analysis (CFA) using AMOS 18.0. The overall measurement model fit indices indicate that the comprehensive confirmatory factor model fits the data well $\left(x^{2}=194.4169\right.$, df $=80, \mathrm{p}=$ $.000, \mathrm{CFI}=.958$, TLI $=.945, \mathrm{NFI}=.931$, standardized RMR $=.030$, RMSEA $=.064)$. The range of Cronbach's alpha coefficients for each construct was acceptable (.708 [Servicescape Quality] .894 [Peer-to-peer Interaction Quality]) and the composite reliability was satisfactory (Table 2). To test convergent validity, $\mathrm{t}$-value and average variance extracted (AVE) were employed (Fornell and Larcker, 1981). T-values of Lambda ( $\lambda$ ) loadings of each measure were significant $(p<.01)$ and AVEs for each construct were good (all exceeded. 70). Overall, the results suggested good convergent validity as shown in Table 2.

Next, discriminant validity was assessed by developing a confidence interval of $\Psi \pm 2 \sigma e$ for each pair of factors and examining whether 1 (one) is included in a confidence interval. The $\Psi$ notation indicates the correlation between two factors, whereas oe represents the standard error between two factors. The high end of the confidence interval between two factors does not include 1, providing evidence of discriminant validity (Koufteros, 1999).

\subsection{Structural model}

Structural equation modeling (SEM) analysis was conducted to test the hypothesized relationships, yielding acceptable model fit indices. The structural model has a statistically significant chi-square test value $\left(x^{2}=268.286\right.$, 
〈Table 2〉 Summary of measurement results.

\begin{tabular}{|c|c|c|c|c|c|}
\hline Construct & $\begin{array}{c}\text { Measurement } \\
\text { items }\end{array}$ & $\begin{array}{l}\text { Factor } \\
\text { Loading }\end{array}$ & T-values & $\begin{array}{l}\text { Composite } \\
\text { reliability }^{\mathrm{a}}\end{array}$ & $\begin{array}{c}\text { Average } \\
\text { variance } \\
\text { extracted } \\
(\mathrm{AVE})^{\mathrm{b}}\end{array}$ \\
\hline \multirow{3}{*}{$\begin{array}{l}\text { Servicescape } \\
\text { Quality }\end{array}$} & V1 & .673 & 12.080 & \multirow{3}{*}{.909} & \multirow{3}{*}{.769} \\
\hline & V2 & .714 & 12.873 & & \\
\hline & V3 & .632 & 11.285 & & \\
\hline \multirow{3}{*}{$\begin{array}{c}\text { Employee-to-customer } \\
\text { Interaction } \\
\text { Quality }\end{array}$} & V4 & .812 & 17.338 & \multirow{3}{*}{.951} & \multirow{3}{*}{.866} \\
\hline & V5 & .810 & 17.292 & & \\
\hline & V6 & .785 & 16.563 & & \\
\hline \multirow{3}{*}{$\begin{array}{l}\text { Peer-to-peer } \\
\text { Interaction } \\
\text { Quality }\end{array}$} & $\mathrm{V7}$ & .869 & 19.828 & \multirow{3}{*}{.939} & \multirow{3}{*}{.837} \\
\hline & V8 & .873 & 19.976 & & \\
\hline & V9 & .835 & 18.686 & & \\
\hline \multirow{3}{*}{$\begin{array}{l}\text { Customer } \\
\text { Experience } \\
\text { Quality }\end{array}$} & V10 & .664 & 13.411 & \multirow{3}{*}{.943} & \multirow{3}{*}{.850} \\
\hline & V11 & .667 & 13.505 & & \\
\hline & V12 & .918 & 20.819 & & \\
\hline \multirow{3}{*}{$\begin{array}{l}\text { Customer } \\
\text { Loyalty }\end{array}$} & V13 & .758 & 15.835 & \multirow{3}{*}{.922} & \multirow{3}{*}{.797} \\
\hline & V14 & .808 & 17.295 & & \\
\hline & V15 & .777 & 16.375 & & \\
\hline
\end{tabular}

Notes:

a Composite reliability: $\left(\sum \lambda \mathrm{i}\right) 2 /\left[\left(\sum \lambda \mathrm{i}\right) 2+\sum \mathrm{ivar}(\varepsilon \mathrm{i})\right]$, where $\lambda \mathrm{i}$ is the component loading to an indicator and $\operatorname{var}(\varepsilon \mathrm{i})=1-\lambda \mathrm{i} 2$.

b Average variance extracted: $\sum \lambda \mathrm{i} 2 /\left[\sum \lambda \mathrm{i} 2+\sum \mathrm{ivar}(\varepsilon \mathrm{i})\right]$.

〈Table 3〉Interconstruct correlations

\begin{tabular}{|c|c|c|c|c|c|}
\hline Variables & $\begin{array}{c}\text { Servicescpe } \\
\text { Quality }\end{array}$ & $\begin{array}{c}\text { Employee-to-customer } \\
\text { Interaction } \\
\text { Quality }\end{array}$ & $\begin{array}{c}\text { Peer-to-peer } \\
\text { Interaction } \\
\text { Quality }\end{array}$ & $\begin{array}{c}\text { Customer } \\
\text { Experience } \\
\text { Quality }\end{array}$ & $\begin{array}{c}\text { Customer } \\
\text { Loyalty }\end{array}$ \\
\hline $\begin{array}{c}\text { Servicescpe } \\
\text { Quality }\end{array}$ & - & .276 & .156 & .263 & .326 \\
\hline $\begin{array}{c}\text { Employee-to-customer } \\
\text { Interaction } \\
\text { Quality }\end{array}$ & $\begin{array}{c}.525 \\
(.029)\end{array}$ & - & .370 & .410 & .341 \\
\hline $\begin{array}{c}\text { Peer-to-peer } \\
\text { Interaction } \\
\text { Quality }\end{array}$ & $\begin{array}{c}.395 \\
. .031)\end{array}$ & $\begin{array}{c}.608 \\
(.027)\end{array}$ & - & .407 & .383 \\
\hline $\begin{array}{c}\text { Customer } \\
\text { Experience } \\
\text { Quality }\end{array}$ & $\begin{array}{c}.513 \\
(.030)\end{array}$ & $\begin{array}{c}.640 \\
(.026)\end{array}$ & $\begin{array}{c}.638 \\
(.030)\end{array}$ & -619 \\
\hline $\begin{array}{c}\text { Customer Loyalty } \\
(.571\end{array}$ & $\begin{array}{c}.584 \\
(.029)\end{array}$ & $.035)$ & .813 & \\
\hline
\end{tabular}

Notes: 1. Intercorrelations are presented in the lower triangle of the matrix. Standard errors appear in the parenthesis. Squared correlations are given in the upper triangle of the matrix. 
$\mathrm{df}=84, \mathrm{p}=.000)$. All other relevant fit indices are also within the acceptable range (CFI $=.932, \mathrm{TLI}=.916$, NFI $=.905$, standardized $\mathrm{RMR}=.047$, RMSEA $=.079$ ). Therefore, we conclude that the proposed model fits the data well. The estimated path coefficients together with hypotheses test results are shown in Figure 2.

The estimated standardized structural coefficients for the hypothesized associations among constructs and their significance are shown in Table 4. The parameter estimates were consistent with the proposed direction in the hypothesized paths and all hypotheses were supported.

As expected, Hypothesis 1, which posits the direct path from the servicescape to customer experience quality, was found to be significant. This indicates that manipulation of the servicescape is likely to enhance customer experience quality. The paths from the servicescape quality to employee-to-customer interaction quality (H2.1) and from employee-to-customer interaction quality to customer experience quality (H2.2) were significant. The paths from the servicescape quality to peer-to-peer interaction quality (H3.1) and from peer-to-peer interaction quality to customer experience quality (H3.2) were also significant. Hypotheses 2 and 3 demonstrate that the indirect paths between the servicescape and customer experience quality via employee-to-customer interaction quality and peer-to-peer interaction quality exists in addition to the direct path between the serv-

〈Figure 2〉 Structural equation model with the estimated path coefficients and test results

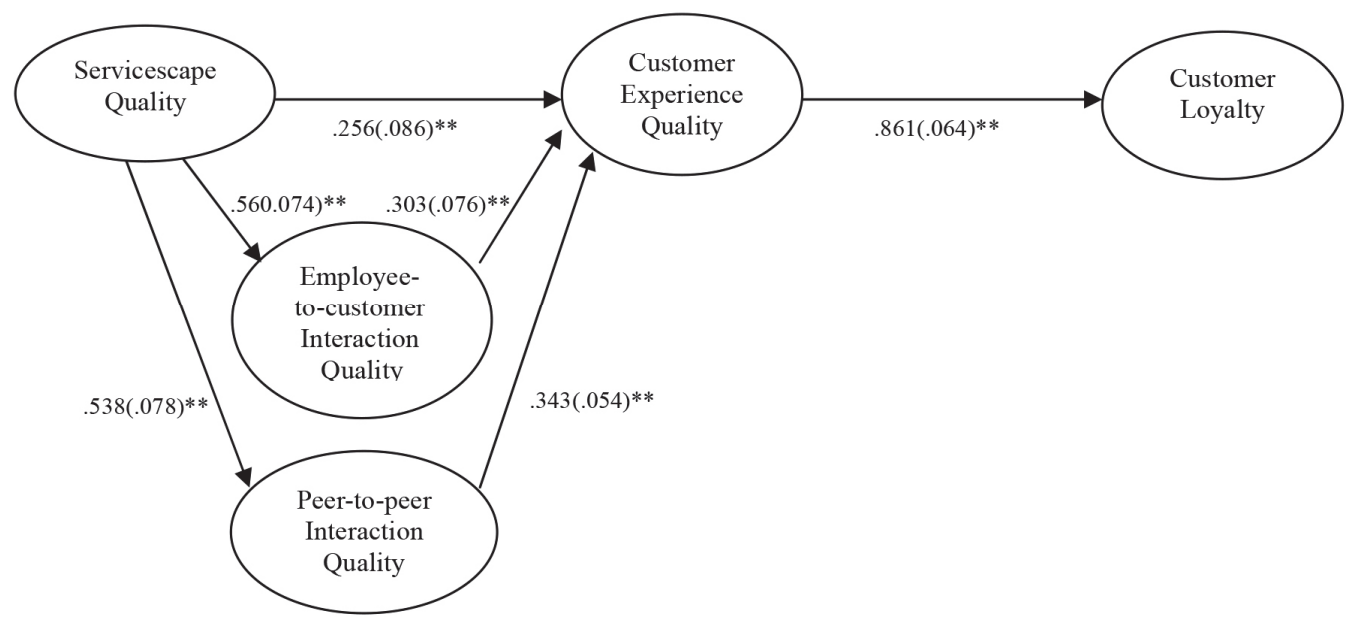

$\begin{aligned} \text { Notes: } & * \mathrm{p}<.05 \\ * * \mathrm{p} & <.01\end{aligned}$

1. Standard errors appear in the parenthesis. 
〈Table 4〉 Structural equation model results: path coefficients

\begin{tabular}{|c|c|c|c|c|}
\hline Hypothesized path & Hypothesis & $\begin{array}{l}\text { Standardized } \\
\text { Coefficient }\end{array}$ & t-Value & Results \\
\hline $\begin{array}{l}\text { Servicescpe Quality } \rightarrow \\
\text { Customer Experience Quality }\end{array}$ & H 1 & .273 & $2.980^{* *}$ & Accepted \\
\hline $\begin{array}{l}\text { Servicescpe Quality } \rightarrow \\
\quad \text { Employee-to-customer Interaction Quality }\end{array}$ & H 2.1 & .634 & $7.532^{* *}$ & Accepted \\
\hline $\begin{array}{r}\text { Employee-to-customer Interaction Quality } \rightarrow \\
\text { Customer Experience Quality }\end{array}$ & H 2.2 & .285 & $3.977^{* *}$ & Accepted \\
\hline $\begin{array}{l}\text { Servicescpe Quality } \rightarrow \\
\text { Peer-to-peer Interaction Quality }\end{array}$ & H 3.1 & .520 & $6.854^{* *}$ & Accepted \\
\hline $\begin{array}{l}\text { Peer-to-peer Interaction Quality } \rightarrow \\
\text { Customer Experience Quality }\end{array}$ & H 3.2 & .378 & $6.351^{* *}$ & Accepted \\
\hline $\begin{aligned} \text { Customer Experience Quality } & \rightarrow \\
& \text { Customer Loyalty }\end{aligned}$ & H 4 & .839 & $13.371^{* *}$ & Accepted \\
\hline
\end{tabular}

icescape and customer experience quality (H1). Customer experience quality also had a significantly positive influence on customer loyalty, lending support for Hypothesis 4. The results support all hypotheses in that all paths are significant and in the expected direction. Overall, the results support our theoretical model and provide empirical evidence regarding the paths between the servicescape and customer experience quality. In addition, the results confirm the link between customer experience quality and customer loyalty.

In an attempt to deepen our understanding of the indirect effects of servicescape quality on customer experience quality via peer-to-peer interaction quality, we further analyzed the moderating role of the level of customer satisfaction on the relationship between service- scape quality and peer-to-peer interaction quality perception, and the relationship between peerto-peer interaction quality perception and customer experience quality in H5. We examined the moderating role of the level of customer satisfaction on the relationship between servicescape quality and peer-to-peer interaction quality, and the relationship between peer-topeer interaction quality and customer experience quality. The results of the chi-square difference test support H5 (see below for details).

\subsection{Moderating effect analysis}

We used a retrospective self-report data approach to investigate the moderating role of the level of customer satisfaction in the suggested model. A two-item, seven-point Likert 
scale, adapted from Fornell et al. (1996), was employed to capture the respondents' perceptions of customer satisfaction. The statements related to perceptions of communication quality were as follows: "Overall, I would say that I am satisfied with XYZ," and "I am satisfied with XYZ compared to other firms." In order to compare samples with high and low satisfaction, we performed a chi-square difference test $\left(\Delta \mathrm{x}^{2}\right)$ consisting of two steps. First, we develop a constraint model by imposing an equality constraint on the focal link. Next, we compare the chi-square between the free model and the constrained model. The participants were divided into two groups of high customer satisfaction and low customer satisfaction based on the median split of customer satisfaction, and each link in the suggested model was compared between the groups.

The results of chi-square difference test indicated that the relationship between service- scape quality and the peer-to-peer interaction quality, and the relationship between the peerto-peer interaction quality and customer experience quality were moderated by the level of customer satisfaction. The results of the chisquare difference test are reported in Table 5.

\section{Discussion and Implications}

\subsection{Contributions}

Designing a servicescape to enhance customer experience quality is different from that for enhancing service quality, since the former must consider a broader set of determinants than the latter. Extending conceptual studies (Lemke et al. 2011; Verheof et al. 2009) that propose a link between the servicescape and customer experience quality, the current study investigates

〈Table 5〉 The moderating effect of the level of customer satisfaction on the relationship between servicescape and peer-to-peer interaction quality, and peer-to-peer interaction and customer experience quality

\begin{tabular}{cccc}
\hline Hypothesized path & $\begin{array}{c}\text { Low-satisfaction } \\
\text { Group } \\
\text { Path Estimates } \\
\text { (S.E.) }\end{array}$ & $\begin{array}{c}\text { High-satisfaction } \\
\text { Group } \\
\text { Path Estimates } \\
\text { (S.E.) }\end{array}$ & $\begin{array}{c}\text { Chi-square } \\
\text { difference } \\
\text { (d.f. difference) }\end{array}$ \\
\hline $\begin{array}{c}\text { Servicescape quality } \rightarrow \\
\text { Peer-to-peer interaction quality }\end{array}$ & $.271(.100)^{* * *}$ & $.018(.104)$ & $3.048(1)^{*}$ \\
$\begin{array}{c}\text { Peer-to-peer interaction quality } \rightarrow \\
\text { Customer experience quality }\end{array}$ & $.253(.079)^{* * *}$ & $.080(.058)$ & $2.922(1)^{*}$ \\
\hline
\end{tabular}


the relationships between the servicescape and customer experience quality, and other constructs such as employee-to-customer interaction quality, peer-to-peer interaction quality, and customer loyalty in hedonic service settings.

The current study contributes to and is distinct from previous research by investigating the indirect effects of the servicescape quality on customer experience quality via peer-to-peer interaction quality in hedonic service settings, the first investigation to the best of our knowledge. Additionally, the present study is the first to highlight the moderating effect of the level of customer satisfaction on the relationship between servicescape quality and peer-to-peer interaction quality, and the relationship between peer-topeer interaction quality and experience quality in hedonic service settings. This study clarifies for researchers the indirect effect of servicescape quality on experience quality via peerto-peer interaction quality, which is significant only in a low-satisfaction customer group, meaning that this factor is a dissatisfier (basic factor) rather than a satisfier (excitement factor) or performance factor.

The current findings demonstrate that, in hedonic service settings, servicescape directly impacts customer experience quality (e.g., service processes take place in servicescape, Bitner, 1992), which in turn influences customer loyalty. This validates previous studies' propositions on the relationship between servicescape and customer experience quality (Lemke et al. 2011;
Verheof et al. 2009). We anticipate that servicescape may be even more critical in self-service environments, as customers should accomplish tasks themselves, though this requires further investigation. The findings also show that the servicescape influences customer experience quality indirectly by influencing interactions between employees and customers, which in turn impact experience quality. For example, the servicescape (e.g., layout, equipment, furnishings, music, size, and the comfort level of a waiting room, etc.) can be used to facilitate interaction between employees and customers, which contributes to the overall quality of the customer's service experience.

Given that the quality of interaction between employees and customers has a significant influence on customer experience quality and the quality of interaction is positively related to servicescape, organizations should seriously consider the ideal servicescape for employees to foster a high level of employee-to-customer interaction. For example, some elements of the servicescape such as equipment, layout, space, and facilities may have a significant influence on employees' motivation and ability to interact with customers as they create desirable environments for employees and often make it easier for employees to engage with customers. On the other hand, ambient cues such as lighting, noise, olfactory cues, and temperature, frequently examined in the previous research on servicescape (Turley and Milliman 2000), may not 
directly enhance employee ability and/or motivation to interact with customers. However, these ambient cues may be considered hygiene factors, so it is important that these be maintained at an acceptable level, as their absence may cause dissatisfaction. Given the substantial implications of this categorization, this could be addressed through future research.

Furthermore, the results demonstrate that servicescape significantly influences customer experience quality indirectly via peer-to-peer interaction quality. The validation of the indirect link between the servicescape quality and customer experience quality via peer-to-peer interaction quality indicates that marketers can facilitate positive customer-to-customer interactions while constraining negative customerto-customer interactions by manipulating the physical environmental parameters. For example, as Bitner suggests in her conceptual paper (Bitner 1992), space and layout can be optimized to facilitate interactions among customers, and temporary friendships created due to such interactions are likely to enhance customer experience. It is also noteworthy that physical settings represent expectations, social rules, and conventions in force in a given behavioral setting, influencing the nature and quality of social interaction (Forgas 1979). We anticipate that the expectations and social rules imposed are likely to encourage comfortable conversations and interaction, and desirable behaviors among the customers, leading to desirable behaviors while discouraging undesirable behaviors. Hence, managers may need to determine the elements to incorporate or modify in the physical setting to enhance the quality of customer-to-customer interactions, as the required changes may differ depending on types of services (e.g., a theme park or a bank).

Interestingly, in hedonic service settings, the indirect effect of servicescape quality on experience quality via peer-to-peer interaction quality is significant only in low customer satisfaction conditions, indicating that it is a dissatisfier rather than satisfier or critical (performance) factor. This result is slightly different from Pollack's (2008) findings. Pollack (2008) examines social factors as a critical (performance) factor, which has a positive linear relationship with satisfaction in hairdresser/barber and phone service settings. By contrast, this study shows that, in hedonic service settings, a significant link from servicescape quality to experience quality via peer-to-peer interaction quality exists only for low satisfaction conditions. In other words, the present study identifies peer-to-peer interaction quality as a dissatisfier factor in hedonic service settings. If customers perceive that the peer-to-peer interaction quality is lacking, customer experience will be greatly affected. The fulfillment of basic requirements is a necessary, but not sufficient condition for customer satisfaction because they are entirely expected. The customer regards them as prerequisites, and they are taken for granted. Johnston (1997) 
suggests that if an evaluation for any dissatisfier factor falls below an acceptable level, it should be addressed first before improving on satisfiers. However, for dissatisfier attributes, the return on quality may diminish after the acceptable level is reached (Pollack 2008), after which point firms cannot achieve great gains in customer satisfaction by improving it (Pollack 2008). Once this point is reached, Pollack (2008) posits that, given scarce management resources, service firms may prefer to allocate resources for quality improvements to the satisfiers. Service managers in hedonic service settings should keep in mind that it is necessary, but not sufficient, to monitor the indirect link from servicescape quality to experience quality via peer-to-peer interaction quality.

The relationship between perceived service quality and brand loyalty has been demonstrated in numerous times in the previous research (Boulding et al. 1993; Gremler and Brown 1996), though the link between customer experience quality and customer loyalty has been scarcely examined (Kim and Choi 2013). It may be partly because customer experience quality has been relatively ignored, drawing less research attention compared to service quality. The present research makes a theoretical contribution by providing additional empirical evidence for the link between customer experience quality and customer loyalty.

Within the real estate business, dead malls are a serious problem. While an issue for decades, it has been worsened due to competition from online shopping combined with economic downturns. Though it may require substantial effort to boost offline shopping sales, offline shopping malls maintain an advantage because they can offer a superior and memorable experience. Of course, "experience" can be provided by online stores but is often limited; you may not have a live band playing music while engaging in conversation with friends or strangers while drinking beer. Though our research does not focus solely on offline shopping experiences but rather overall customer experience, we believe that our research provides insights into the antecedents and consequences of customer experience.

\subsection{Limitations and future research}

The study is subject to several limitations, a discussion of which will help with an appropriate interpretation of the findings. First, the current study does not examine the impact of servicescape on internal responses such as affection. Servicescape elements such as music, temperature, odor, and light are likely to influence mood or elicit various emotional reactions, and emotional responses to the environment may be transferred to other people within the environment (Obermiller and Bitner 1984). Therefore, further research on the impact of servicescape on affection may deepen our understanding of the issue. Second, the present research suggests boosting customer experience quality is crucial 
to enhancing customer loyalty. However, customer loyalty may be influenced by the other variables such as customer satisfaction. We recommend that future research investigate additional factors to extend the applicability of the current model. Third, given the complexity of the relationship between servicescape and customer behavior, we recommend various methods for future research, including experiments, surveys, and direct observation may provide more in-depth information regarding the impact of the physical setting on behavioral responses. Fourth, the current study focuses on the relationship among the overall assessment of servicescape quality, the overall assessment of peer-to-peer interaction quality, and the overall assessment of customer experience quality, so the results have limited applicability to specific concrete attributes. Future research may deepen this research's insights by addressing the relationships among specific concrete servicescape attributes, peer-to-peer interaction quality (see Lee et al. 2009), and customer experience quality. Fifth, this study focuses on hedonic service settings, so caution should be taken when applying the results to other service areas (e.g., banks, hospitals, and retailers). Future research may contribute to the generalizability of this research by addressing diverse service settings.

〈Received April 22. 2015〉

〈Revised July 21. 2015〉

〈Accepted July 22. 2015〉

\section{References}

Ali, C., B. T. Cornwell, D.T. Nguyen, and L. Coote (2006), "Exploring the usefulness of a consumer activity index in the sponsorshiplinked marketing context," International Journal of Sport Marketing and Sponsorship, 7, 115-124.

Albers-Miller, N. D. and M. R. Stafford (1999), "International services advertising: an examination of variation in appeal use for experiential and utilitarian services," Journal of Services Marketing, 13 (4/5), 390-406. Aubert-Gamet, V. and B. Cova (1999), "Servicescapes: From Modern Non-Places to Postmodern Common Places," Journal of Business Research, 44 (1), 37-45.

Bateson, J. and M. K. Hui (1986), "Crowding in the Service Environment," in Creativity in Services Marketing: What's New, What Works, What's Developing, Venkatesan M., Schmalensee D. M. and Marshall C., eds. Chicago: American Marketing Association, $85-88$.

Berry, L. L., L. P. Carbone, and S. H. Haeckel (2002), "Managing the total customer experience," Sloan Management Review, 43, 85-90.

Bitner, M. J. (1992), “The servicescapes: The Impact of Physical Surroundings on Customers and Employees," Journal of Marketing, 56 (2), 57-71. 
Bitner, M. J., B. H. Booms, and M. Lois (1994), "Critical Service Encounters: The Employee's Viewpoint," Journal of Marketing, 58 (4), 95-106.

Bloemer, Josee, K. O. De Ruyter, and Martin Wetzels (1999), "Linking perceived service quality and service loyalty: a multidimensional perspective," European Journal of Marketing, 33 (11/12), 1082-1106.

Boulding, W., A. Kalra, A. Staelin, and V. A. Zeithaml (1993), "A dynamic process model of service quality: From expectations to behavioral intentions," Journal of Marketing Research, 30 (1), 7-27.

Brady, M. K. and J. Cronin (2001), "Some New Thoughts on Conceptualizing Perceived Service Quality: A Hierarchical Approach," Journal of Marketing, 65 (3), 34-49.

Caru, A. and B. Cova (2003), "Revisiting consumption experience: A more humble but complete view of the concept," Marketing theory, 3 (2), 267-286.

Caru, A. and B. Cova (2015), "Co-creating the collective service experience," Journal of Service Management, 26(2), 276-294.

Choi, B. and H. S. Kim (2013), "The impact of outcome quality, interaction quality, and peer-to-peer quality on customer satisfaction with a hospital service," Managing Service Quality, 23 (3), 188-204.

Churchill, G. A. Jr. (1979), “A Paradigm for Developing Better Measures of Marketing Constructs," Journal of Marketing Research,
$16(1), 64-73$.

Clark, T. and C.L. Martin (1994), "Customerto-Customer: The Forgotten Relationship in Relationship Marketing," in Proceedings of the Research Conference on Relationship Marketing Theory, Method, and Applications, Emory University, Atlanta, GA, 1-10. Cooper-Martin, E. (1992), “Consumers and movies: information sources for experiential products," Advances in Consumer Research, 19 (1), 751-761.

Douglas, S. P. and C. S. Craig (1983), International Marketing Research, Englewood Cliffs, NJ: Prentice-Hall.

Fisher, J. D. and D. Byrne (1975), "Close for Comfort: Sex Differences in Response to Invasions of Personal Space," Journal of Personality and Social Psychology, 32 (1), 15-21.

Forgas, J. P. (1979), Social Episodes. London: Academic Press, Inc.

Fornell, C. and D. F. Larcker (1981), "Evaluating Structural Equation Models with Unobservable Variables and Measurement Error," Journal of Marketing Research, 18 (1), 39-50.

Fornell, C., M. D. Johnson, E. W. Anderson, J. Cha, and B.E. Bryant (1996), "The American customer satisfaction index: nature, purpose, and findings," Journal of Marketing, 60 (4), 7-18.

Fullerton, R. A. and G. Punj (1993), "Choosing to Misbehave: A Structural Model of 
Aberrant Consumer Behavior," Advances in Consumer Research, 20, 570-574.

Gremler, Dwayne D., Mary Jo Bitner, and Kenneth R. Evans (1994), "The Internal Service Encounter," International Journal of Service Industry Management, 5 (2), 34-56.

Gremler, D. D. and S. W. Brown (1996), "Service loyalty: its nature, importance, and implications," in Edvardsson, B. (Eds.), Advancing Service Quality: A Global Perspective, International Service Quality Association, 171-180.

Grönroos, C. (1982), Strategic Management and Marketing in the Service Sector. Helsingfors: Swedish School of Economics and Business Administration.

Grönroos, C. (1984), “A Service Quality Model and Its Marketing Implications," European Journal of Marketing, 18 (4), 36-44.

Harris, K. and S. Baron (2004), "Consumer-toconsumer conversations in service settings," Journal of Service Research, 6 (3), 287-303. Hightower, R. Jr, M.K. Brady, and T. L. Baker (2002), "Investigating the role of the physical environment in hedonic service consumption: an exploratory study of sporting events," Journal of Business Research, 55, 697-707.

Johnston, R. (1997), "Identifying the critical determinants of service quality in retail banking: importance and effect," The International Journal of Bank Marketing,
15 (4), 111-116.

Kim, H. S. and B. Choi (2013), "The Influence of Customer Experience Quality on Customers' Behavioral Intentions," Services Marketing Quarterly, 34 (4), 322-338.

Klaus, P. and S. Maklan (2012), "EXQ: a multiple-item scale for assessing service experience," Journal of Service Management, 23 (1), 5-33.

Koufteros, X. A. (1999), "Testing a model of pull production: a paradigm for manufacturing research using structural equation modeling," Journal of Operations Management, 17 (4), 467-488.

Kozinets, R. V. (1999), "E-Tribalized Marketing? The Strategic Implications of Virtual Communities of Consumption," European Management Journal, 17 (3), 252-264.

Lam, S. Y., V. Shankar, M. K. Erramilli, and B. Murthy (2004), "Customer value, satisfaction, loyalty, and switching costs: an illustration from a business-to-business service context," Journal of Academy of Marketing Science, 32 (3), 293-311.

LaSalle, D. and T. Britton (2003), Priceless: Turning Ordinary Products into Extraordinary Experiences, Harvard Business School Press, Boston, MA.

Lee, J. Y., H. S. Kim, and S. La (2009), “An exploratory study on customer-to-customer contact quality using CIT," Journal of Korean Marketing Association, 24(3), 71-93.

Lemke, F., M. Clark, and J. Wilson (2011), 
"Customer Experience Quality: An Exploration in Business and Consumer Contexts Using Repertory Grid Technique," Journal of the Academy of Marketing Science, 39 (6), 846-869.

Lovelock, C. H. (1994), Product Plus: How Product and Service Equals Competitive Advantage, New York: McGraw-Hill.

Lovelock, C. H. (2001), Services Marketing: People, Technology, Strategy, $4^{\text {th }}$ ed. Englewood Cliffs, NJ: Prentice Hall.

Martin, C. L. (1996), "Consumer-to-Consumer Relationships: Satisfaction with Other Consumers' Public Behavior," Journal of Consumer Affairs, 30 (1), 146-169.

McGrath, M. A. and C. Otnes (1995), "Unacquainted Influencers: When Strangers Interact in the Retail Setting," Journal of Business Research, 32, 261-272.

Martin, C. L. and C. A. Pranter (1989), "Compatibility Management: Customer-to-Customer Relationships in Service Environments," Journal of Services Marketing, 3 (3), 5-15. Matzler, K., F. Bailom, H. H. Hinterhuber, B. Renzl, and J. Pichler (2004), "The asymmetric relationship between attribute-level performance and overall customer satisfaction: a reconsideration of the importanceperformance analysis," Industrial Marketing Management, 33 (4), 271-277.

Meyer, C., and A. Schwager (2007), "Understanding customer experience," Harvard Business Review, 85 (2), 117-126.
Moschis, G. P. and D. Cox (1989), "Deviant Consumer Behavior," Advances in Consumer Research, 16, 732-737.

Mohr, L. A. and M. J. Bitner (1995), "The Role of Employee Efforts in Satisfaction with Service Transactions," Journal of Business Research, 32 (3), 239-252.

Ng, S., R. Russell-Bennett, and T. Dagger (2007), "A typology of mass services: the role of service delivery and consumption purpose in classifying service experiences," Journal of Services Marketing, 21 (7), 471-480.

Nguyen, D. T., T. DeWitt, and R. RussellBennett (2012), "Service convenience and social servicescape: retail vs hedonic setting," Journal of Services Marketing, 26 (4), 265-277.

North, A. C., A. Shilcock, and D. J. Hargreaves (2003), "The Effect of Musical Style on Restaurant Customers' Spending," Environment and Behavior, 35 (5), 712-718.

Obermiller, C., and M. J. Bitner (1984), "Store Atmosphere: A Peripheral Cue for Product Evaluation," in American Psychological Association Annual Conference Proceedings, Consumer Psychology Division, David C. Stewart ed. American Psychological Association, 52-53.

O'Shaughnessy, J. and N. J. O'Shaughnessy (2002), "Marketing, the consumer society and hedonism," European Journal of Marketing, 36 (5/6), 524-547. 
Podsakoff, P. M., S. B. MacKenzie, J.-Y. Lee, and N.P. Podsakoff (2003), "Common method biases in behavioral research: a critical review of the literature and recommended remedies," Journal of Applied Psychology, 88(5), 879-903.

Pollack, B. L. (2008), "The nature of the service quality and satisfaction relationship: empirical evidence for the existence of satisfiers and dissatisfiers," Managing Service Quality, 18 (6), 537-558.

Prahalad, C. K. and V. Ramaswamy (2004), "Co-Creation Experiences: The Next Practice in Value Creation," Journal of Interactive Marketing, 18 (3), 5-14.

Payne, A. F., K. Storbacha, and P. Frow (2008), "Managing the Co-creation of Value," Journal of the Academy of Marketing Science, 36, 83-96.

Reimer, A., and R. Kuehn (2005), "The impact of servicescape on quality perception," European Journal of Marketing, 39 (7/8), 785-808.

Shaw, C. and J. Ivens (2005), Building Great Customer Experiences. MacMillan, New York. Shostack, G. L. (1985), "Planning the Service Encounter," in J.A. Czepiel, M.R. Solomon, and C.F. Surprenant (eds.), The Service Encounter, Lexington, MA: Lexington Books, 243-254.

Sirdeshmukh, D., J. Singh, and B. Sabol (2002), "Consumer Trust, Value, and Loyalty in Relational Cxchanges," Journal of Marketing,
66 (1), 15-37.

Sommer, R. (1974), Tight Spaces: Hard Architecture and How to Humanize It. Englewood Cliffs, NJ: Prentice-Hall, Inc. Spangenberg, E. R, A. E. Crowley, and P. W. Henderson (1996), "Improving the Store Environment: Do Olfactory Cues Affect Evaluations and Behaviors," Journal of Marketing, 60 (2), 67-80.

Sundstrom, E., and M. G. Sundstrom (1986), Work Places. Cambridge, UK: Cambridge University Press.

Tax, S.S., S.W. Brown, and M. Chandrashekaran (1998), "Customer evaluations of service complaint experiences: Implications for relationship marketing," Journal of Marketing, 62 (2), 60-76.

Tombs, A. G. and J. R. McColl-Kennedy (2010), "Social and spatial influence of customers on other customers in the social-servicescape," Australasian Marketing Journal, 18 (3), 120-131.

Turley, L. W. and R. E. Milliman (2000), "Atmospheric Effects on Shopping Behavior: A Review of the Experimental Evidence," Journal of Business Research, 49 (2), 193-211.

Verhoef, P. C., K.N . Lenon, A. Parasuraman, A. Roggeveen, M. Tsiros, and L.A. Schlesinger (2009), "Customer Experience Quality: Determinants, Dynamics and Management Strategies," Journal of Retailing, 85 (1), 31-41. 
Wakefield, K. L., and J. G. Blodgett (1996), "The effect of the servicescape on customers' behavioral intentions in leisure service settings," Journal of Services Marketing, 10 (6), 45-61.

Wu, C. H. J. (2007), "The Impact of Customerto-customer Interaction and Customer Heterogeneity on Customer Satisfaction in Tourism Service- The Service Encounter Prospective," Tourism Management, 28, 1518-1532.
Yim, C. K., D. K. Tse, and K. W. Chan (2008), "Strengthening customer loyalty through intimacy and passion: Roles of customerfirm affection and customer-staff relationships in services," Journal of Marketing Research, 45 (6), 741-756.

Zeithaml, V. A., L. L. Berry, and A. Parasuraman (1996), "The Behavioral Consequences of Service Quality," Journal of Marketing, 60 (2), 31-47. 